\title{
Exploring Beliefs of Pre-Service Mathematics Teachers: A Malaysian Perspective
}

\author{
Mazlini Adnan \\ Faculty of Education and Human Development \\ Universiti Pendidikan Sultan Idris, Tg. Malim, Perak, Malaysia \\ E-mail: mazlini@fst.upsi.edu.my \\ Effandi Zakaria \\ Faculty of Education \\ Universiti Kebangsaan Malaysia, Bangi, Selangor, Malaysia \\ E-mail: effandi@ukm.my
}

\begin{abstract}
The purpose of this study was to determine the beliefs of pre-service mathematics teachers. This study involved 83 respondents from the pre-service teachers from a public higher education institution (IPTA) in Malaysia. The instruments used in this study consist 42 items of mathematics beliefs. There are three dimensions in these instruments, namely beliefs about mathematics as nature, beliefs about learning mathematics and beliefs about the teaching of mathematics. The findings showed that pre-service teacher's beliefs mathematics can be used in everyday life. For the beliefs about learning mathematics, the respondents agreed that students should be able to give reasons to support each solve mathematical problems. Finally, about the beliefs on mathematics teaching, the respondents agreed that the teaching of mathematics to students should be encouraged by explaining the mathematical ideas.
\end{abstract}

Keywords: Mathematical beliefs, Pre-service teachers

\section{Introduction}

In the 21 st century, the challenge of globalisation demands that the people of Malaysia to become more knowledgeable, skilled, disciplined and emphasise quality. To realise these challenges, the key individuals who should bear the responsibility are the teachers. This is because the teacher is a person who is in the best front line in an effort to educate current and future generations to realise the challenge. So it can be said of responsibility and demands of the teachers are called far greater.

Therefore, the responsibility to be as a teacher today is far more challenging compared to teachers in the previous decade. This is a result of globalisation, liberalisation and development of ICT that requires all people who feel that the teacher is responsible for the greater efforts needed to produce students who have self-esteem, moral character and can compete regardless of national or international stage. In fact, this task could be realised with the availability of quality teachers through effective teaching, providing exemplary leadership and personality that can be a good example to all children. Therefore, this task can be undertaken with care if every prospective teacher has quality academic ability and personality so that the future generation will be excellence, and glorious in education.

\section{Mathematics Beliefs}

Research on teachers' beliefs and goals are common among many researchers in educational research as well as research on teachers' practices. But in recent years, a trend of research on the relationship between teachers' beliefs in practice has been regarded as an important issue in mathematics education (Vacc et al., 1999; Borko et al., 1992; Raymond, 1997; Francis, 1992; Simon et al., 2000). Knowledge and beliefs held by a teacher influenced their practices and behaviour in the classroom (Simon, et al. 2000; Vacc et al., 1999; Calderhead, 1996; Richardson et al., 1991).

There are many studies shows that teachers' beliefs influence student beliefs (Lester \& Garofalo, 1987; Chapman, 2001). It is generally accepted, and widely known about what the teacher was (teacher knowledge) will influence 
what will be taught by the teacher to student, and will eventually also affect students (Dougherty, 1990; Ball \& McDiarmid, 1990; Fennema \& Franke, 1992). In addition, pre-service teachers' beliefs about mathematics teaching and pedagogical content knowledge can influence the decisions or the selection method of teaching (Pajares, 1992; Prawat, 1992; Thompson, 1992). New teachers as they taught mostly in teaching (Lortie, 1975; Noyes, 2004). Thus, it is important to investigate the beliefs of mathematics among pre-service teachers as there are studies that showed that teachers' beliefs is one of the factors that are to guide the selection of an action learning process (Thompson, 1992). The study also found that teachers' beliefs were used in determining how teachers will teach either he realised it or not (Lester \& Garofalo, 1987). For example, if a teacher believes that mathematics is learned through memorisation and teaching is spacious with lots of rules so the teacher will also emphasise memorization more than a conceptual understanding of mathematics itself. In addition, there are also teachers believe the goal of solving a mathematical problem that just to get the correct answer (Ball \& Feiman-Nemser, 1988).

Understanding the beliefs of pre-service teachers is very important in mathematics education to help them develop and implement an effective teacher education programmes (Barlow \& Reddish, 2006). This is because beliefs of mathematics as a mathematics as nature, mathematics teaching and learning can affect their teaching in school (Beswick, 2005). This will also influence their attitudes (McLeod, 1992). Teachers who take mathematics education carry with them a variety of experiences based on their beliefs. Individually they interpret their own experience and it brought to the mathematics classroom with prejudice and bias that exists. The findings showed that trust in the service of teachers play a vital role in securing and interpretation of knowledge and experience. It is also responsible for a less effective teaching practice (Thompson, 1992).

Mathematical beliefs can influence their beliefs and their conception. Negative beliefs teachers pre-service students will affect their future, and this cycle will be prolonged. Studies show that prospective teachers do not like math, believe they will fail, and also believe that mathematics can only be understood by some students only (Evan, 2003). The study also found that perception of pre-service teachers that mathematics consists of facts, procedures and regulations to be memorised (Thompson, 1992). This understanding, is not prevented from the outset to be carried to the classes that they teach mathematics. This will encourage teachers to teach only to the understanding of the procedure only and not on conceptual understanding. Understanding the beliefs of student teachers are very important for mathematics educators to help them design and implement an effective teacher education programmes (Barlow \& Reddish, 2006).

Teachers' beliefs about mathematics have an enormous impact on teaching practices (Hart, 2002; Buchman, 1987; Hall, 2005; Beswick, 2006; Golafshani, 2002, 2005; Charalambos, Philippou \& Kyriakides, 2002; Ernest, 1988, 1989, 2000; Putnam, Prawat \& Remillard, 1992 ; Perrin-Glorian, Deblois \& Robert, 2008). The study by Samuelsson (2008) found that nearly $80 \%$ of respondents in the study of pre-service teachers who were interviewed had negative feelings toward mathematics. Studies show that prospective teachers do not like math, believe they will fail, and also believe that mathematics can only be understood by some students (Evan, 2003). The study also found that pre-service teachers have the perception that mathematics consists of facts, procedures and regulations that need to be memorised (Dossy, 1992; Thompson, 1992). This understanding, if not prevented from the outset to be carried to the classes they teach mathematics will have a negative effect on students performance. This will encourage teachers to teach only to the understanding of the procedure only and not on conceptual understanding. Therefore, the pre-service teachers' beliefs are an important element to be studied in each teacher education programme (Llinares, 2002). Thus, there is a need to assess whether the beliefs held pre-service teachers of mathematics, mathematics teaching and learning.

\section{Research Objectives}

The objective of this study was to determine the beliefs of pre-service mathematics teachers. Based on the objective, the following research questions are drawn for this study:

1. What are the beliefs about mathematics as nature held by pre-service teachers?

2. What are the beliefs about learning mathematics held by pre-service teachers?

3. What are the beliefs about mathematics teaching held by pre service teachers?

\section{Methodology}

The research design is a survey study. This study used a questionnaire on beliefs in mathematics. Mathematics Beliefs Questionnaire (MBQ) which was adapted from Hart (2002) has 42 items with three dimensions that include beliefs about mathematics as nature, beliefs about learning mathematics and beliefs about mathematics teaching. This questionnaire divided into three sub construct of beliefs about mathematics as nature (10 items), 
beliefs about learning mathematics (13 items) and beliefs about teaching mathematics (19 items). The Cronbach alpha's value for MBQ was 0.76 . The reliability value for all items was 0.87 which can be considered good (Hair et al., 1988). Each respondent should answer all the items submitted and the time allocated to complete this questionnaire is 30 minutes.

They were 83 pre-service teachers who participated in this study. There are from a public institution of higher learning (IPTA) in Malaysia. The respondents are a third year pre service teachers of mathematics education who are taking mathematics as a major.

\section{Results and Discussion}

\subsection{Profile of Respondents}

The study involved 83 pre-service teachers from one institution. They are majoring in mathematics and they are in their sixth semester. Overall, the profiles of the respondents are shown in Table 1.

The respondents mainly comprised of women, (75.9\%) were female and the remaining 20 (24.1) were the male. There were 66 Malay respondents (79.5\%). This was followed by the 13 Chinese (15.7\%) and 3 natives from Sabah / Sarawak (3.6\%). There was 1 Indian respondent (1.2\%). Linear Algebra for the subject was used, the number of respondents who received the excellence were 34 (41.0\%) of the total. Respondents with good were $24(28.9 \%)$, moderate $21(25.2 \%)$ and week $4(4.8 \%)$. To subject the beginning of calculus, the largest number of respondents for both were 39 men $(47.0 \%)$. The medium has excellence and the same respondents $20(24.1 \%)$ and weak 4 (4.8\%).

\subsection{Beliefs about mathematics as a nature held by pre-service teacher}

According to Table 2, the item "Mathematics is essentially an abstract subject," the highest percentage is on a scale of "Agree" that a total of 55.4\%. For the item "Mathematical reasoning involved in solving problems", the highest percentage is also on the scale of "Agree" with this item is of $69.9 \%$. For the third item of "Mathematics can be used in everyday life", the percentage is the highest and second highest on the scale of "Strongly Agree", and "Agree". Percent of the scale "Strongly Agree" with this item is of $77.1 \%$.

There are 10 items used to measure beliefs about mathematics among pre-service teachers. Of these items, item number 6 of "mathematics can be used in everyday life" shows how often "Strongly Agree" the highest compared to other items of a total of $77.1 \%$. This shows that pre-service teachers alike believe that mathematics can be used in our daily lives. The result is consistent with the findings of Lazim and Abu Osman (2009). It is also among the most important element of knowledge required in each individual to be applied in everyday life.

\subsection{Beliefs about learning mathematics held by pre-service teachers}

According to Table 3, the item "In mathematics, students need to understand all the concepts, principles and strategies of solving in mathematics, the percentage is the highest and second highest on the scale of" Agree "and" Strongly Agree ". The percentage of scale "Agree" with this item is of $60.2 \%$. For the item "In mathematics, students should be trained in the procedures before the calculation is given in the form of mathematical problem solving", the highest percentage is on a scale of "Agree". The percentage of scale "Agree" with this item is of $61.4 \%$. For the third item of "In learning mathematics, students should be able to give reasons to support each solve mathematical problems, the highest percentage is on a scale of "Agree ". The percentage of scale "Agree" with this item is of $78.3 \%$. For the item "In mathematics, students need frequent practice", the highest percentage is on a scale of "Strongly Agree" that is $57.8 \%$.

There are 13 items to measure beliefs about mathematics learning among pre-service teachers, item number 31 of "In learning mathematics, students should be able to give reasons to support each solve mathematical problems" shows the frequency of "Agree" the highest compared to other items of a $78.3 \%$. This shows that pre-service teachers alike agree that the learning of mathematics, they believe students should be able to give reasons to support each solve mathematical problems. Give reasons to support every mathematical problem is one of the most important element of knowledge required in each individual that called for teachers to be applied in teaching and learning of mathematics. The result is an advantage to students in the pre-service teachers had beliefs and the realization that the understanding of mathematical concepts is very important to apply to the disciples.

\subsection{Beliefs about mathematics teaching held by pre-service teachers}

According to Table 4, the item "Teaching mathematics should involve the investigation and findings by the students themselves", the highest percentage is on a scale of "Agree". The percentage of scale "Agree" with this item is of $59.0 \%$. For the item "Mathematics should be taught as a set of concepts, skills, and the calculations, 
the highest percentage is on a scale of" agree ". The percentage of scale "Agree" with this item is of $66.3 \%$. For the third item is "In the teaching of mathematics, students should be encouraged to explain their mathematical ideas", the highest percentage is on a scale of "Agree". The percentage of scale "Agree" with this item is of $69.9 \%$. For the item "Teachers should guide students who have difficulties in solving mathematical word problems", the highest percentage is on a scale of "Strongly Agree" that is 50.6\%.

There are 19 items to measure beliefs about the teaching of mathematics in pre-service teachers, item number 10 that "the teaching of mathematics, students should be encouraged to explain their mathematical ideas" showed that the frequency of "Agree" was the highest compared with other items of a total of $69.9 \%$. This shows that pre-service teachers alike believe that the teaching of mathematics, students should be encouraged to explain their mathematical ideas.

\section{Conclusion}

This study aimed to investigate the beliefs of mathematics among pre-service teachers of mathematics in Malaysia. Mathematical beliefs held by pre-service teachers were an important aspect that needs to be studied. Therefore, a detailed study, the views from various parties and also the effect of short-term and long term that might occur should be noted accordingly. The effect here means that either positive or negative effects that may arise as a result of the beliefs held by the pre-service teachers. We do not want future generations to hold on to produce some of the beliefs that may lead to a more progressive party and one of the more declining.

\section{References}

Adams, T. L. (1998). Prospective elementary teachers' mathematics subject matter knowledge: The real number system. Action in Teacher Education, 20(2), pp.35-48.

Ball, D. L. and Feiman-Nemser, S. (1988). Using textbooks and curriculum guides: A dilemma for beginning teachers and teacher educators. Curriculum Inquiry, 18 (4), pp. 401- 422.

Ball, D. L. (1989). Breaking With Experience In Learning To Teach Mathematics: The Role Of A Pre-service Methods Course. The Annual Meeting of the American Educational Research Association, San Francisco, March 1989.

Ball, D.L. and McDiarmid, G.W. (1990). The subject matter preparation of teachers. In W.R. Houston (Eds.), Handbook of Research of Teacher Education. New York: Macmillian.

Barlow, A. T. and Reddish, J. M. (2006). Mathematical myths: Teacher candidates' beliefs and the implications for teacher educators. The Teacher Educator, 41, pp.145-157.

Beswick, K. (2005). The beliefs/practice connection in broadly defined contexts. Mathematics Education Research Journal, 17(2), pp.39-68.

Beswick, K. (2006). The importance of mathematics teachers' beliefs. Australian Mathematics Teacher, 62(4), pp. 17-22.

Borko, H., Eisenhart, M., Brown, C. A., Underhill, R. G., Jones D. and Agard, P. C. (1992). Learning to teach hard mathematics: Do novice teachers and their instruction give up too easyly ? Journal for Research in Mathematics Education. 23(3), pp.194 - 222.

Brown, C. and Borko, H. (1992). Becoming a mathematics teacher. In D. Grouws (Eds.), Hand-book of Research on Mathematics Teaching and Learning (pp. 209-239). NewYork: Macmillan.

Bryan, T. J. (1999). The conceptual knowledge of pre-service secondary mathematics teachers: How well do they know the subject matter they will teach? Issues in the Undergraduate Mathematics Preparation of School Teachers: The Journal. Volume 1: Content Knowledge. [Online] Available: http://www.k-12prep.math.ttu.edu/journal/journal.shtml 22 February 2010.

Buchmann, M. (1987). Teaching knowledge: The lights that teachers live by. Oxford Review of Education, 13, pp. 151-164.

Bush, W.S. (1982). Pre-service Secondary Mathematics Teachers' Knowledge about Teaching Mathematics and Decision Making Processes during Teacher Training. Unpublished doctoral dissertation University of Georgia.

Caine, R.N. and Caine, G.C. (1998). Building a bridge between the Neurosciences and education: Cautions and possibilities. Bulletin. 82(598), pp.1-8.

Calderhead, J. (1996). Teachers: Beliefs and Knowledge. In Berliner, D.C. \& R.C. 
Chapman, O. (2001). Understanding high school mathematics teacher growth. In M. van den Heuvel-Panhuizen (Eds.), Proceedings of the 25th Annual Meeting of the International Group for the Psychology of Mathematics Education. Utrecht: Utrecht University.

Charalambos, C., Philippou, G., and Kyriakides, L. (2002). Towards understanding teachers' philosophical beliefs about mathematics. Paper presented at the International Group for the Psychology of Mathematics Education (PME), Norwich UK.

Conference Board of Mathematical Sciences (CBMS). (2001). The Mathematical Education of Teachers. Providence RI and Washington DC: American Mathematical Society and mathematical Association of America.

De Corte, E. and Op't Eynde, P. (2002). Unraveling student's belief systems relating to mathematics learning and problem solving. In Rogerson, A. (Eds.). Proceeding of the International Conference "The humanistic renaissance in mathematics education", pp. 96-101.

Dewey, J. (1938). Experience and education. New York: Macmillan.

Dougherty, B. J. (1990). Influence of teacher cognitive/conceptual levels on problem solving instruction. In G. Booker et al., Eds., Proceedings of the fourteenth international conference for the psychology of mathematics education (pp. 119-126). Oaxtepec, Mexico: International Group for the Psychology of Mathematics Education.

Ernest, P. (1994). Impact of belief on the teaching of mathematics. Paper presented for ICME, VI, Budapest, Hungary.

Ernest, P. (1988). The Impact of Beliefs on the Teaching of mathematics. In P. Ernest (Eds.), Mathematics Teaching: The State of the art, (pp. 249-254). London: Falmer. [Online] Available: http://www.ex.ac.uk/ PErnest/impact.htm (pp. 1-5).

Ernest, P. (1989). The knowledge, beliefs and attitudes of the mathematics teacher: A model. Journal of Education for Teaching, 15 (1), pp.113-33.

Ernest, P. (2000). Teaching and learning mathematics. In V.Koshy, P. Ernest, and R. Casey (Eds.), Mathematics for primary teachers. London, UK: Routledge.

Evans, B. D. (2003). Early childhood (K-5) pre-service teachers' beliefs about mathematics, teaching mathematics, and learning mathematics. Dissertation. Georgia Southern University. ProQuest Document Information and Learning 12 May 2008.

Feinman Nemser, S. (1983). Learning to teach. In S. L. Shulman et G, Sykes (Eds.), Handbook of teaching and policy. New York: Longman Inc.

Fennema, E. and Franke, M. L. (1992). Teachers' knowledge and its impact. In D. Grouws, Eds., Handbook of research on mathematics teaching and learning (pp. 147-164). New York: Macmillan Publishing Company.

Francis, E. J. (1992). The concept of limit in college calculus: Assessing student understanding and teacher beliefs (Limit concept) (Doctoral dissertation, University of Maryland). Dissertation Abstracts International, A $53 / 10,3465$.

Frykholm, J. (2000). A missing piece in secondary mathematics teacher education. Focus On Learning Problem In Mathematics, 22, pp.27-44.

Fuller, R. A. (1996). Elementary teachers' pedagogical content knowledge of mathematics. Paper presented at the Mid-Western Educational Research Association Conference, Chicago, IL.

Golafshani, N. (2002). Teachers' conceptions of mathematics and their instructional practices. Philosophy of Mathematics Education Journal, 15.

Golafshani, N. (2005). Secondary teachers' professed beliefs about mathematics, mathematics teaching and mathematics learning: Iranian perspective. $\mathrm{PhD}$ thesis, University of Toronto.

Goulding, M., Rowland, T. and Barber, P. (2002). Does it matter? Primary teacher trainees' subject knowledge in mathematics. British Educational Research Journal, 28(5), pp.689-704.

Hall, L. A. (2005). Teachers and content area reading: Attitudes, beliefs and change. Teaching and Teacher Education, 21, pp. 403-414.

Hart, L. E. (2002). Pre-service teachers' beliefs and practice after participating in an integrated content/ methods course. School Science and Mathematics, 102 (1). pp 4-15.

Jackson, P. W. (1986). The practice of teaching. New York: Teachers College Press. 
Kagan, D. M. (1992). Implications of research on teacher belief. Educational Psychologist, 27(1), pp. 65-90.

Lester, F. K. dan Garofalo, J. (1987). The influence of affects, beliefs, and metacognition on problem-solving behavior: Some tentative speculations. Paper presented at the annual meeting of American Educational research Association, Washington, D. C.

Liljedahl, P. (2005). Changing beliefs, changing intentions of practices: the re-education of preservice teachers of mathematics. 15th Study of the International Commission on Mathematics Instruction. Aguas de Lindoia, Brazil, May 2005.

Llinares, S. (2002). Participation and reification in learning to teach: The role of knowledge and beliefs. In Leder, G.C., Pehkonen, E. \& Törner, G. (Eds.), Beliefs: A Hidden Variable in Mathematics Education?, pp. 195-209. The Netherlands: Kluwer Academic Publishers.

Lortie, D. (1975). Schoolteacher: A Sociological Study. Chicago, IL: University of Chicago Press.

M.A. Lazim, and M.T.Abu Osman. (2009). Measuring Teachers' Beliefs about Mathematics: A Fuzzy Set Approach. International Journal of Social Sciences, 4(1).

Ma, L. (1999). Knowing and teaching elementary mathematics: Teachers' understanding of fundamental mathematics in China and the United States. Mahwah, N.J.: Lawrence Erlbaum Associates.

Martinez, J. G. R. and Martinez, N. C. (1996). Math without fear. Needham Heights, MA: Allyn and Bacon.

McDiarmid, G. W., Ball, D. L., dan Anderson, C. A. (1989). Why staying one chapter ahead doesn't really work: Subject-specific pedagogy. In M. Reynolds (Eds.), Knowledge base for the beginning teacher (pp. 193-205). Oxford, UK: Pergamon.

McLeod, D. B. (1992). 'Research on affect in mathematics education: A reconceptualization. In D.A.Grouws (Eds.), Handbook of Research on mathematics teaching and learning. New York Macmillan, pp. 575-596.

National Research Council (NRC). (2001). Adding it up: Helping children learn mathematics. J. Kilpatrick, J. Swafford, and B. Findell (Eds.). Mathematics Learning Study Committee, Center for Education, Division of Behavioral and Social Sciences and Education. Washington, DC: National Academy Press.

Noorashikin Ibrahim. (2003). Pedagogical content knowledge of mathematics teacher in algebra. Master of Education. Research Project. Bangi: Universiti Kebangsaan Malaysia.

Noyes, A. (2004). “The Poetry of the Universe”: New Mathematics Teachers' Metaphoric Meaning-Making. Proceedings of the 28th Conference of the International Group for the Psychology of Mathematics Education, 2004. Vol 3, pp. 441-448.

Nyaumwe, L. (2004). The impact of full time student teaching on preservice teachers' conceptions of mathematics teaching and learning. Mathematics Teacher Education and Development, 6, pp.23-36.

Op't Eynde, P., De Corte, E. dan Verschaffel, L. (1999). Balancing between cognition and affect: students' mathematic-related beliefs and their emotions during problem solving, pp. 97-105. Mathematical beliefs and their impact on teaching and learning of mathematics. Universiti Duisburg, 21-27 November.

Pajares, M.F. (1992). Techers beliefs and educational research: Cleaning up a messy construct. Review of Educational Research, 62(3), pp.307-332.

Perrin-Glorian, M. J., Deblois, L. and Robert, A. (2008). In K. Krainer \& T. Wood (Eds.) Participants in Mathematics Teacher Education: Individuals, Teams, Communities and Networks (pp. 35 - 59). Rotterdam, Sense. (Volume 3 of The International Handbook of Mathematics Teacher Education.

Powell, R.R. (1992). The influence of prior experiences on pedagogical constructs of traditional and non-traditional pre service teachers. Teaching \& Teacher Education, 8(3). pp 225-238.

Prawat, R. S. (1992a). Teachers' beliefs about teaching and learning: A constructivist perspective. American Journal of Education, 100(3), pp. 354-395.

Prawat. R. S. (1992b). Are changes in views about mathematics teaching sufficient? The case of a fifth-grade teacher. Elementary School Journal, 93, pp. 195-211.

Proulx, J. (2007). Addressing the issue of the mathematical knowledge of secondary mathematics teachers. Proceedings of the 31st Conference of the International Group for the Psychology of Mathematics Education (Vol. 4, pp. 89-96). Seoul, the Republic of Korea: Seoul National University. 
Putnam, R. L., Heaton, R. M., Prawat, R. S., and Remillard, J. (1992). Teaching mathematics for understanding: Discussing case studies of four fifth-grade teachers. Elementary School Journal, 93, pp. 213-228.

Quillen, A. M. (2004). Relationships among prospective elementary teachers' beliefs about mathematics, mathematics content knowledge, and previous mathematics course experiences. Dissertation. Virginia Polytechnic Institute and State University. SCIRUS Document 13 May 2008.

Raymond, A. M. (1997). Inconsistency between a beginning elementary school teacher's mathematics beliefs and teaching practice, Journal for Research in Mathematics Education, 28, pp.550-576.

Richardson, V., Anders, P., Tidwell, D., and Lloyd, C. (1991). The relationship between teachers' beliefs and practices in reading comprehension instruction. American Educational Research Journal, 28, pp. 559-586.

Samuelsson, J. (2008). Student Teachers' Experiences with Math Education. [Online] Available: www.usca.edu/essays/vol192007/samuelsson\%5B1\%5D.pdf (February 23, 2010).

Schön, D. (1983). The reflective practitioner: How professionals think in action. New York: Basic Books.

Schuck, S. and Foley, G. (1999). Viewing mathematics in new ways: Can electronic learning communities assist? Mathematics Teacher Education and Development, 1, pp. 22-37.

Shulman, J. (1987). From veteran parent to novice teacher: A case study of a student teacher. Teaching and Teacher Education, 3, pp.13-27.

Simon, M,. A., Tzur, R., Heinz, K. and Kinzel, M. (2000). Characterizing a perspective underlying the practice of mathematics teachers in transition. Journal for Research in Mathematics Education, 30(4), pp.579 - 601.

Skott, J. (2001). The emerging practices of novice teachers: The roles of his school mathematics images. Journal of Mathematics Teacher Education, 4(1), pp. 3-28.

Stacey, K., Helme, S., Steinle, V., Baturo, A., Irwin, K. and Bana, J. (2001). Pre-service teachers'knowledge of difficulties in decimal numeration. Journal of Mathematics Teacher Education, 4(3), pp.205-225.

Tengku Zawawi Tengku Zainal. (2000). Kurikulum Matematik sekolah bestari. Jurnal Akademik Maktab Perguruan Kuala Terengganu, 11, pp. 4-11.

Thompson, A.G. (1992). Teachers' beliefs and conceptions: A synthesis of the research. In A.D. Grouws (Eds.), Handbook of research on mathematics teaching and learning (pp. 127-146). New York: Macmillan.

Tirosh, D. (2000). Enhancing prospective teachers' knowledge of children conceptions: The case of division of fractions. Journal for Research In Mathematics Education, 30(1), pp. 5-25.

Vacc, N. N. and Bright, W. B. (1999). Elementary preservice teachers; changing beliefs and instructional use of children's mathematics thinking. Journal for Research in Mathematics Education, 29(1), pp.89 - 110.

Wilson, S., Floden, R. and Ferrini-Mundy, J. (2001). Teacher preparation research:Current knowledge, gaps, and recommendations. A research report prepared forthe U.S. Department of Education. University of Washington, Center for theStudy of Teaching and Policy. Seattle.

Zazkis, R. and Campbell, S. (1996). Divisibility and multiplicative structure of natural numbers: Preservice teachers' understanding. Journal for Research in Mathematics Education, 27(5), pp. 540-563.

Table 1. Profile of Respondents

\begin{tabular}{llcc}
\hline \multicolumn{1}{c}{ Profile } & & Frequency (f) & Percentage \\
\hline Gender & Male & 20 & 24.1 \\
& Female & 63 & 75.9 \\
\hline Race & Malay & 66 & 79.5 \\
& Chinese & 13 & 15.7 \\
& Indian & 1 & 1.2 \\
& Natives of Sabah/Sarawak & 3 & 3.6 \\
\hline Linear Algebra & Excellent & 34 & 41.0 \\
& Good & 24 & 28.9 \\
& Moderate & 21 & 25.2 \\
\hline
\end{tabular}




\begin{tabular}{llll}
\hline & Weak & 4 & 4.8 \\
\hline Beginning Calculus & Excellent & 20 & 24.1 \\
& Good & 39 & 47.0 \\
& Moderate & 20 & 24.1 \\
& Weak & 4 & 4.8 \\
\hline
\end{tabular}

Table 2. Beliefs about Mathematics

\begin{tabular}{lccccccccccc}
\hline \multirow{2}{*}{ Item } & \multicolumn{2}{c}{ SD } & \multicolumn{1}{c}{ D } & \multicolumn{2}{c}{ MD } & \multicolumn{2}{c}{ A } & \multicolumn{2}{c}{ SA } \\
\cline { 2 - 11 } & f & $\mathbf{\%}$ & $\mathbf{f}$ & $\mathbf{\%}$ & $\mathbf{f}$ & $\mathbf{\%}$ & $\mathbf{f}$ & $\mathbf{\%}$ & $\mathbf{f}$ & $\mathbf{\%}$ \\
\hline Mathematics is primarily an abstract subject & 4 & 4.8 & 8 & 9.6 & 14 & 16.9 & 46 & 55.4 & 11 & 13.3 \\
& & & & & & & & & & \\
\hline Mathematics is about reasoning in solving problem & 0 & 0.0 & 1 & 1.2 & 4 & 4.8 & 58 & 69.9 & 20 & 24.1 \\
\hline Mathematics is applicable & 0 & 0.0 & 0 & 0.0 & 1 & 1.2 & 18 & 21.7 & 64 & 77.1 \\
\hline
\end{tabular}

Table 3. Beliefs about Mathematics Learning

\begin{tabular}{llcccccccccc}
\hline \multicolumn{1}{c}{ Item } & \multicolumn{2}{c}{ SD } & \multicolumn{1}{c}{$\mathbf{D}$} & \multicolumn{2}{c}{ MD } & \multicolumn{2}{c}{ A } & \multicolumn{2}{c}{ SA } \\
\cline { 2 - 9 } & f & $\mathbf{\%}$ & $\mathbf{f}$ & $\mathbf{\%}$ & $\mathbf{f}$ & $\mathbf{\%}$ & $\mathbf{f}$ & $\mathbf{\%}$ & $\mathbf{f}$ & $\mathbf{\%}$ \\
\hline $\begin{array}{l}\text { In learning mathematics, student should understand } \\
\text { mathematical concepts, principles, and strategies }\end{array}$ & 0 & 0.0 & 0 & 0.0 & 3 & 3.6 & 50 & 60.2 & 30 & 36.1 \\
\hline $\begin{array}{l}\text { Time should be spent practicing computational } \\
\text { procedures before student spend much time solving } \\
\text { problem }\end{array}$ & 0 & 0.0 & 3 & 3.6 & 12 & 14.5 & 51 & 61.4 & 17 & 20.5 \\
\hline $\begin{array}{l}\text { In learning mathematics, student should be able to } \\
\text { provide reasons to support their solutions }\end{array}$ & 1 & 1.2 & 2 & 2.4 & 6 & 7.2 & 65 & 78.3 & 9 & 10.8 \\
\hline
\end{tabular}

Table 4. Beliefs about Mathematics Teaching

\begin{tabular}{|c|c|c|c|c|c|c|c|c|c|c|}
\hline \multirow[t]{2}{*}{ Item } & \multicolumn{2}{|c|}{ SD } & \multicolumn{2}{|c|}{ D } & \multicolumn{2}{|c|}{ MD } & \multicolumn{2}{|c|}{$\mathbf{A}$} & \multicolumn{2}{|c|}{ SA } \\
\hline & $\bar{f}$ & $\%$ & f & $\%$ & f & $\%$ & f & $\%$ & $\mathbf{f}$ & $\%$ \\
\hline $\begin{array}{l}\text { Mathematics instruction should involve the investigation } \\
\text { and findings by the students themselves }\end{array}$ & 0 & 0.0 & 6 & 7.2 & 18 & 21.7 & 49 & 59.0 & 10 & 12.0 \\
\hline $\begin{array}{l}\text { Mathematics SHOULD be taught as a COLLECTION of } \\
\text { concepts, skills and algorithms }\end{array}$ & 0 & 0.0 & 1 & 1.2 & 14 & 16.9 & 55 & 66.3 & 13 & 15.7 \\
\hline $\begin{array}{l}\text { In mathematics lesson, students should be encourage to } \\
\text { explain their math ideas }\end{array}$ & 0 & 0.0 & 3 & 3.6 & 7 & 8.4 & 58 & 69.9 & 15 & 18.1 \\
\hline
\end{tabular}

